\title{
CRITICAL CULTURAL AWARENESS: SHOULD VIETNAMESE CULTURE BE TAUGHT IN A DIFFERENT WAY?
}

\author{
Do Nhu Quynh*, Dao Thi Dieu Linh \\ VNU University of Languages and International Studies \\ Pham Van Dong, Cau Giay, Hanoi, Vietnam \\ Received 17 September 2019 \\ Revised 27 November 2019; Accepted 14 February 2020
}

\begin{abstract}
Critical cultural awareness - the key component in the framework of intercultural communicative competence of Byram (1997) - highlights the importance of training critical thinking skills for foreign language learners. Much research has been conducted on how critical cultural awareness can be developed in language classrooms, yet very few takes classroom of native culture as a fertile context for raising such awareness. This paper is to highlight the necessity of fostering that awareness in native culture classroom. We would clarify how the conventional way of teaching Vietnamese culture at the University of Languages and International Studies is inconducive to build up critical cultural awareness for learners by critiquing the essentialism that the two course books based on and the lack of dynamic reflections of stereotypical ideas for learners via the observation of teachers and students. We then proposed some ideas to make teaching and learning practices more critical.**
\end{abstract}

Keywords: critical cultural awareness, Vietnamese culture, essentialism, dynamic

\section{Introduction}

Michel Byram (1997) framed the fivedimension model of intercultural competence, of which four dimensions, namely knowledge, skills of interpreting, skills of interaction, attitude of openness/curiosity, follow a clockwise circle starting from knowledge, and the last dimension-critical cultural awareness - at the center of this circle. The first four dimensions served as the pre-requisite for the latter construct - the competence that every world language speaker should have.

* Corresponding author. Tel.: 84-983909318

Email: quynh.dnq@vnu.edu.vn

** This research has been completed under the sponsorship of the University of Languages and International Studies (ULIS, VNU) under the Project N.17.08

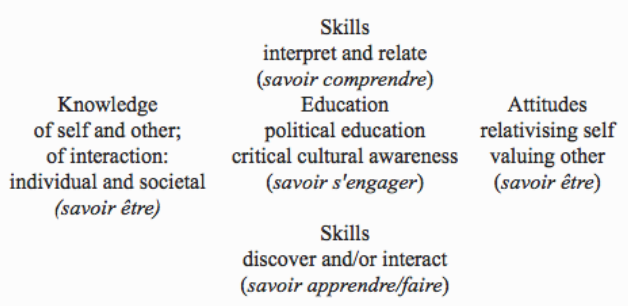

Figure 1. Byram's model of Intercultural Communicative Competence (1997, p. 34)

According to Oxford Learners' Dictionary, "critical" means "expressing disapproval of somebody/something and saying what you think is bad about them"; however, in the educational context of Byram's model, "critical" is more likely to hold its 1640s' etymological meaning of "having the knowledge, ability or discernment to pass judgement". In his book, Byram (1997) claimed, "Finally, in an educational 
framework which aims to develop critical cultural awareness, relativisation of one's own and valuing others' meanings, beliefs and behaviours does not happen without a reflective and analytical challenge to the ways in which they have been formed and the complex of social forces within which they are experienced" (p. 35, emphasis added). Building critical cultural awareness means a constant reflection upon how our beliefs are discursively constructed in a particular social, cultural and historical context. Though it is impossible for an individual to "annul the effects of stereotypes" (Truong \& Phung, 2019, p. 99), understanding the complex of social forces that form a belief does help suspending stereotypical perceptions. Delaying judgement, and then passing it, is therefore much more valuable and humane than expressing disapproval towards other interlocutors, as it has the power to unweave any potential intercultural misunderstandings. The term critical cultural awareness, thereafter, refers to one's awareness of differences among cultures on the basis of passing judgement, not on showing tension.

Of the five dimensions, knowledge is the starting point. It can either be a door to openness or a door to lonesomeness. If the knowledge of a person is just bounded by the wisdom of a local community where he or she was born, that person's perception of the world will be shaped by some very limited points of view. Nonetheless, if a person lacks the local wisdom, he or she would be easily assimilated to a new culture and devalue his or her own culturally native society. The point here is the dynamic interrelationship, like what Sercu pointed out, "I would add that savoirs includes both culture-specific (of own and foreign culture) and culturegeneral knowledge; as well as the knowledge regarding many ways in which culture affects language and communication" (2010, p. 77). When the interrelationship among cultures is manifested, it helps diminish the monolithic perception of the native
English speaker's culture, or even the local culture, as mainstream ways of thinking and behaving (Alptekin, 2002). Knowledge of specific cultures has an important role to play in developing the awareness of cultural differences; however, what truly requires our attention is "an understanding of the dynamic way sociocultural contexts are constructed" (Baker, 2011, p. 4, emphasis added)

Central on the key term dynamic, we believe that the intercultural competence can be developed in foreign language practices via two factors: (1) the dynamic knowledge of native culture and (2) the dynamic reflection of preconceived ideas towards oneself and others from target culture.

When reviewing the papers written on intercultural communicative competence (i.e. Crozet, 1996; Liddicoat, 2005; Newton, 2016), the authors noticed that this competence is usually associated with foreign language teachers; however, in our perspectives, teachers teaching native culture should share that role with their counterparts. Unlike language teachers who are often restrained by the skillbased or test-preparation practices, teachers of culture can take advantage of the content on beliefs and values that are conducive to intercultural reflection and implications.

With that mindset, we would critique the way Vietnamese culture is taught at University of Languages and International Studies (ULIS), with two main arguments in accordance with the two factors mentioned above: firstly, the static nature of the materials in use; and secondly, the nonreflectional teaching and learning practices. When critiquing the materials, we do not say that they are bad references for learning Vietnamese culture; instead, we aim at their inappropriateness in regard to official sources to develop critical cultural awareness. In terms of non-reflectional teaching and learning practices, we collect data from informal interviews with teachers of Vietnamese culture and from survey questionnaires with students of this course. 


\section{Three steps towards critical cultural awareness}

Within the framework of intercultural communicative competence, Byram (1997) defines critical cultural awareness as "an ability to evaluate critically and on the basis of explicit criteria perspectives, practices and products in one's own and other cultures and countries" (p. 53). Though this definition is originally constructed for a language classroom, it seems more achievable in culture classroom as students have a higher chance to directly expose to "perspectives, practices and products" of their own culture.

According to Nugent and Catalano (2015), the first step in the process toward building critical cultural awareness is that "students must be given time to identify and reflect upon their preconceived ideas, judgments, and stereotypes toward individuals from the target culture" (p. 17). Byram (1997) argued that people, being affected by their social ecology or what is shaped in the media, often unconsciously bring their stereotypical ideas into intercultural conversations. Those stereotypes are not only towards other cultures, but towards oneself as well: Who we think we are? We navigate ourselves in which position: inferior, superior or equal? It can be very dangerous for the conversation when both interlocutors have false predetermined expectations to their counterpart. Learners therefore need to be aware of their stereotypes before participating in any intercultural talk.

Furthermore, this step is to unmask students' ideologies (Byram, 2008) and "critically evaluate ideological concepts they possibly lead to intercultural conflict" (Yulita, 2013, p. 205). After acknowledging the stereotypes, we need to walk a step further by figuring out what patterns of thought such as: Marxism, Capitalism, Confucianism, Buddhism, or Romanticism, are driving us in this society. If one person realizes that he or she is a small part in a repertoire of ideologies, he or she can avoid the essentialist idea of himself or herself and become humbler in communication.

The second step in the process toward critical cultural awareness begins when students engage in tasks that encourage thoughtful and rational evaluation of perspectives, products and practices related to the target culture (Byram, 1997). This step plays a crucial role in postponing judgement because instead of spontaneously concluding how a person is like, a person needs to question and reason for their beliefs about the target culture.

The final step in developing critical cultural awareness is to create real or simulated opportunities for interactions with individuals of diverse cultural backgrounds and worldviews (Byram, 1997). People often say "practice makes perfect" and this step gives learners an opportunity to practice communicating and negotiating beliefs.

In the scope of this paper, the researchers would focus on the first step. We believe that the identification and reflection upon the preconceived ideas are fundamental in shaping critical cultural awareness of intercultural communicative competence.

\section{Research methods}

This paper adopts both qualitative and quantitative approach in order to collect evidences from multiple respects to back up for the argument that the Vietnamese culture should be taught differently. In Section 5.1, the researchers use the content analysis method to analyze the two books and critique their patterns. In Section 5.2.1, an informal interview was conducted to elicit insights from teachers of Vietnamese culture. For Section 5.2.2, the researchers solicited the view of students from a survey questionnaire before carrying out follow-up interview for further investigation. 


\section{Overview of teaching and learning Vietnamese culture at ULIS}

In 1995 - the year in Đổi Mới stage (Đổi Mới was an economic reform in 1986) and the dawn of globalization - the Vietnam Ministry of Education officially promulgated Fundamentals of Vietnamese Culture (Co. sở văn hoá Việt Nam) as a compulsory subject in the tertiary education curriculum. In the following years, the University of Languages and International Studies adopted the Vietnamese culture course for first-year students. The course accounts for 3 credits with 30 hours of lecture in class and 15 hours for self-study. Since 2014, the Division of Vietnamese language and culture has applied blended learning approach for this course, with 9 hours in-class for orientation and sumup and 36 hours of online learning.

The three compulsory course books are Fundamentals of Vietnamese Culture (Co sở văn hoá Việt Nam) of Trần Ngọc Thêm (1997), the book with the same title of Trần Quốc Vượng (1998), and Searching for the True Nature of Vietnamese Culture (Tìm về bản sắc văn hoá Việt Nam) of Trần Ngọc Thêm (1996).

\section{Discussion}

\subsection{The static patterns of materials in use}

The first highlight of the two books called Fundamentals of Vietnamese Culture is that they all follow the typological-systematic view $^{1}$ appearing in the book Searching for the True Nature of Vietnamese Culture (Tim về bản sắc văn hoá Việt Nam) of Trần Ngọc Thêm (1996). The premise of this view rooted in the tenets of racial categorization, in which the categorization of cultures must begin with an understanding of the

\footnotetext{
Trần Quốc Vượng self-claimed in Chapter 2: The structures, institutions and functions of culture that he used the findings from Trần Ngọc Thêm's research on ways of categorizing cultures (p. 66)
}

formation and distribution of human races on the earth in general ${ }^{2}$, and the environmental determinism, which means that the habitat conditions would determine the fundamental cultural patterns distinguishing the Eastern and Western civilizations ${ }^{3}$. Trần Quốc Vượng stated, "Căn cứ theo nguồn gốc, ta gọi chúng là văn hoá gốc nông nghiệp, và văn hoá gốc du mục. Điển hình cho loại gốc nông nghiệp (trọng tĩnh) là các nền văn hoá phương Đông." (Based on the origin, we categorized them into agricultural culture and nomadic culture. A typical [illustration] for the agricultural culture, which values the static, is the Eastern civilization [and therefore Western civilization belongs to nomadic culture].) (1998, p. 71). Also, in this divide, the "authentic" East refers to the Southeast Asia, and the "authentic" West refers to the Northwest Asia - Europe today; the whole region in between the two areas above is deemed to be "vùng đệm" (the buffer zone) (Trần Ngọc Thêm, 1997, p. 16) .

2 Trần Ngọc Thêm wrote, "Văn hoá là sản phẩm của con người (tính nhân sinh), cho nên việc phân loại văn hoá cần bắt đầu từ việc tìm hiểu sự hình thành và phân bố các chủng người trên trái đất." (Culture is a human product (human nature), so the classification of culture should start from understanding the formation and distribution of the human race on earth.) (1996, p. 37)

3 Trần Ngọc Thêm wrote in his book, "Theo cấu trúc 4 thành tố và trên cơ sở những khác biệt về điều kiện kinh tế và môi trường cư trú, phần 2 đi tìm những đặc trưng cơ bản nhất cho phép phân biệt các nền văn hoá phương Đông với các nền văn hoá phương Tây mà xét theo nguồn gốc có thể gọi là loại hình văn hoá gốc nông nghiệp và loại hình văn hoá gốc du mục." (Following a four-component structure and based on differences in economic conditions and residence, Part 2 seeks out the most basic characteristics that distinguish Eastern culture - the agricultural culture - from Western cultures - the nomadic culture.) (p. 20)

4 Trần Ngọc Thêm wrote “...trong lịch sử ở cựu lục địa Âu-Á đã hình thành hai vùng văn hoá lớn là "phương Tây" và "phương Đông": Phương Tây là khu vực tâybắc gồm toàn bộ châu Âu (đến dãy Uran); phương Đông gồm châu Á và châu Phi; nếu trừ ra một vùng 
The second highlight of the two books lies in the clear-cut chronological transition of Vietnam historical-cultural process, though the word historical is not directly mentioned. In his book, Trần Ngọc Thêm wrote, "Tiến trình văn hóa Việt Nam có thể chia thành sáu giai đoạn: văn hóa tiền sử, văn hóa Văn Lang - Âu Lạc, văn hóa thời chống Bắc thuộc, văn hóa Đại Việt, văn hóa Đại Nam và văn hóa hiện đại." (The process of Vietnamese culture can be divided into six stages: prehistoric culture, Van Lang - Au Lac culture, anti-Northern colonial culture, Dai Viet culture, Dai Nam culture and modern culture.) (1997, pp. 30-41). The same thing was also recorded in Chapter 3 of Trần Quốc Vượng's book. "Vietnam"1 appeared in their prose as experiencing a sharp movement from one culture to the other without any involvements from the previous ones.

In our perspective, the cultural dynamic crucial for developing intercultural competence could only be achieved under two conditions: Firstly, the materials of culture must stress on the fluidity, not the static "authenticity", of each culture; secondly, the acculturalization process within that culture and with other cultures is not a positive trajectory. With this stand, the two books of Trần Ngọc Thêm and Trần Quốc Vượng seem to be inappropriate in building critical awareness for students. We will explain below.

đệm như một dài đường chéo chạy dài ở giữa từ tâynam lên đông-bắc thì phương Đông điển hình sẽ là khu vực đông-nam còn lại.” ( “... in the history of the former Eurasian continent, two major cultural regions, "Western" and" Eastern", have been formed: the West is the northwestern region of the whole of Europe (up to the Uran Mountains); the East includes Asia and Africa; if subtracting a buffer zone as a long diagonal line running in the middle from southwest to northeast, the East would typically be the remaining southeastern region.") (1996, p. 16)

1 "Vietnam" is put in quotation mark because it implies different meanings in different historical periods.

2 The researchers intentionally use quotation mark for this term as we do not believe that any culture is truly authentic.
Firstly, the patterns of thoughts in his book show that the two authors viewed culture as a constant. They argued that the primeval racial split has been determining "the East" and "the West" like today. Trần Ngọc Thêm stated, "Lâu nay trên thế giới phổ biến cách phân chia nhân loại thành ba đại chủng Á (Mongoloid, trong cách nói dân gian thường gọi là chủng da vàng), chủng Âu (Europeoid, dân gian thường gọi là chủng da trắng) và chủng ÚcPhi (Australo-Negroid, dân gian thường gọi là chủng da đen) $[. .$.$] Căn cứ vào những đặc$ điểm trung tính, không thay đổi trước những biến động của môi trường (như nhóm máu, đường vân tay, hình thái răng...) người ta đã chia nhân loại thành hai khối quần cư lớn: Úc Á và Phi-Âu - đó cũng chính là hai trung tâm hình thành chủng tộc cổ xưa nhất của loài người: Trung tâm phía Tây (Phi-Âu) và Trung tâm phía Đông (Úc-Á)" (1996, p. 37) (The past scholars had argued that there were three main human races: Mongoloid, Europeoid, and Australo-Negroid [...] Based on the neutral and unchanged patterns (blood group, finger print, teeth structure), it is now more common to divide human into two main groups: AfricaEurasia and Australia-Asia - the two most ancient race-formation centers of human beings: The West center and the East center). This argument is not persuasive because: firstly, how can the primeval split of homo sapiens of more than 2 million years ago ${ }^{3}$ still fiercely determine the 21 st-century cultures?; and secondly, Trần Ngọc Thêm mis-cited this argument from the book of Cheboksarov (1971). Cheboksarov did mention the racial split, but he later on emphasized, "Later on people of the Homo sapiens species, settling throughout the globe, absorbed more ancient populations on the periphery of the primitive Ecumene $^{4}$, conserving the neutral features and

3 This estimation was taken from: Harari, Y. N. (2014). Sapiens: A brief history of humankind. Canada: McClelland \& Stewart.

4 The Ecumene was an ancient Greek term for the known, the inhabited, or the habitable world. (Wikipedia) 
adjusting to new environmental conditions, and diversified into the modern races." (p. 60). Unlike Trần Ngọc Thêm, Cheboksarov supplemented for his first arguments of two "race-formation centers" with the idea that human beings changed over time. We do not see that changing-over-time reasoning in Trần Ngọc Thêm's book-writing philosophy. More noticeably, he concluded, "Các nền văn hoá hiện đại dù đang thuộc giai đoạn văn mình nào (nông nghiệp, công nghiệp, hay thậm chí hậu công nghiệp) cũng đều không thoát ra ngoài hai loại hình ấy." (No matter at what stage of civilization cultures today might be at (agricultural, industrial or even postindustrial), they cannot escape the two basic cultural forms [of valuing the static or valuing the dynamic].) (1996, p.41). We wonder how this mindset could help our country "xây dựng một nền văn hoá tiên tiến, đậm đà bản sắc dân tộc" (build an advanced culture imbued with national identity). The "national identity" may be, yes, but the "progressive", we are not sure as Trần Ngọc Thêm himself viewed it as a constant.

Secondly, the typological-systematic view, as Liam C. Kelly (also known as Lê Minh Khải) argued, probably results in racialist attitude (Le, 2016). As he argued in his 5-part series "Racism in Vietnamese Scholarship", the typological-systematic view rooted from the Orientalist knowledge produced by Said (1978) that the East and the West constituted a pair of opposites. As implied from Said's book called Orientalism, this "knowledge"

\footnotetext{
Trần Ngọc Thêm wrote in the Preface: "Những năm gần đây, văn kiện của Đảng và Nhà nước Việt Nam nhiều lần khẳng định vai trò quan trọng của văn hóa trong việc bồi dưỡng và phát huy nhân tố con người, đồng thời đặt mục tiêu "xây dựng một nền văn hóa tiên tiến, đậm đà bản sắc dân tộc"”. ( "In recent years, documents of the Party and State of Vietnam have repeatedly affirmed the important role of culture in fostering and promoting the human factor, and at the same time set the goal of "building an advanced culture imbued with national identity",") (1997)
}

was used to justify Western imperialism as an effort to "rule it and regenerate it for the sake of the world at large" (Al-Marky, 1979, p. 82). Trần Ngọc Thêm and Trần Quốc Vượng, in countering this at-time dominating ideology, portrayed how "good" the Orient ${ }^{2}$ are. Trần Quốc Vượng wrote, "Sống hoà hợp với thiên nhiên là mong muốn của cư dân các nền văn hoá trọng tĩnh phương Đông [...] Bởi vậy mà các nên văn hoá phương Tây trọng động mang trọng mình tham vọng chinh phục và chế ngự thiên nhiên [...] Và, vấn đề của con người không phải là chiến thắng thiên nhiên mà sống trong một sự hoà hợp có ý thức và tế nhị với thiên nhiên." (Living in harmony with nature is the desire of the residents of the Eastern static cultures [...] Therefore, the important Western cultures focus on their ambition to conquer and overpower nature [...] And, the problem of man is not conquering nature but living in a conscious and delicate harmony with nature.) (1998, pp. 71-72) After stating the orientation of each culture, he showed his own opinion of good-bad, and non-tacitly praised the "delicate harmony with nature" of the East. This view has committed cultural bias in the sense that either the West is "good" or the East is "good" falls into the trap of stereotypical generalization. Added to that, the way Trần Ngọc Thêm refers to other regions outside the East and West as "vùng đệm" (the buffer zone) also shows a stereotypical attitude towards those regions. The learners, if not actively expose to multicultural input, will stuck in the East-West network of meanings, which indeed has the power of segregation itself. As Ludwig Wittgenstein, a distinguished Austrian philosopher of $20^{\text {th }}$ century, edicted, "The limits of my language mean the limits of my world." (2001), the choice of words in Trần Ngọc Thêm's book might not help a cultural learner overcome impulsive judgements.

Thirdly, the linear transition from one cultural civilization to the other would be

\footnotetext{
2 The term "Orient-East" was used in opposite with "Occident-West"
} 
inconceivable. The movement of cultural exchanges does not follow a vertical direction with 6 stages as written in the book of Trần Ngọc Thêm: prehistoric culture (around 3000 years BC), to Van Lang - Au Lac culture (from 3000 years $\mathrm{BC}$ to several centuries $\mathrm{BC}$ ), to anti-Sino colonial culture (from several centuries $\mathrm{BC}$ to $10^{\text {th }}$ century $\mathrm{AD}$ ), to Dai Viet culture (from $10^{\text {th }}$ century AD to $18^{\text {th }}$ century AD), to Dai Nam culture (from $18^{\text {th }}$ century AD to $1850 \mathrm{~s}$ ) and to modern culture (from late $19^{\text {th }}$ century to present). The first evidence for our argument is the continuous acculturalization with other cultures. During Dai Viet culture stage, Vietnamese culture evolved with sporadic Chinese invasions and colonization, such as the 30 -year period being dominated by the Ming Dynasty. An image of "authentic" or "consistent" Dai Viet culture could be unobtainable due to that frequent acculturalization. Further evidence is in the 15 th century before Le Loi's victory. During that period, most of the Confucius books and documents were burned down by the invaders, not to mention the customs and habits were assimilated, so we cannot say that Dai Viet culture now developed independently from the Sino culture. Interestingly, at the same age, gunpowder manufacturing techniques in Vietnam - the seeds of "modern" culture - achieved brilliant achievements, no less comparable to the West (Goscha, 2016, p. 59).

As Phan Ngọc (1996), a late $20^{\text {th }}$ century scholar of Vietnam, analyzed, "Trong người tôi và bạn có đủ yếu tố của năm nền văn hoá. Tôi họ Phan, đó là văn hoá Trung Quốc. Đến cơ quan tôi bắt tay cả bạn nam lẫn bạn nữ. Đó là văn hoá phương Tây. Trên người tôi từ đầu đến chân đều Âu hoá và tôi có khả năng quy định sự thay đổi này theo năm tháng. Nhưng về nhà tôi giao lương cho vợ và vợ tôi làm chủ hầu hết mọi việc trong nhà. Đó là văn hoá Đông Nam Á. Khi viết bài này tôi suy nghĩ bằng tiếng Pháp nhưng viết tiếng Việt (văn hoá Đông Nam Á) để tránh những hiểu lầm tiếng Việt tự nó có thể gây nên. Chữ viết này là gốc châu Âu, ngôn ngữ đầy từ gốc Hán và những cách diễn đạt sao phỏng của Pháp. Khi viết, tôi cố gắng trình bày theo quan điểm Mác (văn hoá xã hội chủ nghĩa) nhưng sử dụng thao tác luận của văn hoá hậu công nghiệp. Cái gì ở tôi cũng là kết hợp." (You and I have all the elements of five cultures. My surname - Phan, rooted in China. At the office, I shake hands with both men and women. It is Western culture. My costumes have been Europeanized from head to toe and I am able to regulate this change over the years. But when I get home, I give my wife all my salary and my wife manages most of the housework. It reflects Southeast Asian culture. When writing this article, I think in French but write in Vietnamese (Southeast Asian culture) to avoid the misunderstandings that Vietnamese itself could cause. This script is of European origin, yet the language is full of Chinese words and French metaphorical expressions. When I write, I try to present it from the Marxist perspective (socialist culture) but using the epistemology of postindustrial culture. Everything about me is a combination.) (p. 132). Vietnamese culture that we shall see nowadays, therefore, cannot be, and should not be deemed as "thuần tuý Việt Nam" (purely Vietnamese). We are not against the way Trần Ngọc Thêm identified cultures along the time axis, but disagree that he did not highlight the interspersion of multiple cultural layers within one culture.

Lastly, the search for "true nature" or "purity" is itself a frivolous and futile effort. Phan Ngọc claimed, "Rõ ràng không có văn hoá không pha trộn, cô lập. Ở thế giới này mọi thứ đều đan xen vào nhau." (Obviously there is no unmixed, isolated culture. Everything is intertwined in this world.) (1996, p. 166). Or Spencer-Oatey also highlighted, "Should the ethnographer return several years after completing a cultural study, he or she would not find exactly the same situation, for there are no cultures that remained completely static year after year [...] Although smallscale, technologically simple, preliterate societies tend to be more conservative (and, 
thus, change less rapidly than modern, industrialized, highly complex societies), it is now generally accepted that, to some degree, change is a constant feature of all cultures." (2012, p. 12).

\subsection{Teaching and learning do not encourage} dynamic reflection of preconceived ideas through teachers' and students 'insights

\subsubsection{From teachers' insights}

We fortunately had chance to talk with 2 Vietnamese culture teachers at ULIS, whose names are Minh An and Minh Anh (pseudonames), about their teaching experiences. The non-structured interview was conducted in an informal setting among colleagues under no institutional pressure. The talk reveals itself with some significant points as below:

Firstly, they praised Trần Ngọc Thêm and Trần Quốc Vượng for showing "plentiful" and "interesting" knowledge of Vietnamese culture. Minh An even got excited when introducing us the "lately-published" book called Searching for True Nature of Vietnamese Culture of Trần Ngọc Thêm. She encouraged us to read the book as she thought it was "much better" than the previous one. We were wondering how "lately-published" the book is, because this book was published in 1996, just a year after the previous book called Fundamentals of Vietnamese Culture (1st Ed.) (1995). However, this concern is just peripheral. The two informants' point of view is to advocate for the books.

Secondly, though they favored the two books, they did not think that it can help learners in developing the intercultural competence. As they explained, the main in-class content is to "introduce the cultural components to learners" without any comparison to the foreign cultures. Students' in-class presentation mainly reports the course books and adds on some pictures that they found on the internet. Recently, this subject has been transformed to online learning. Students need merely 15 minutes per week to finish the multiple choice exercises on the online learning system. Both teachers agreed that this way of learning, though it can boost students' learning autonomy, is "of no help to their cultural acquisition".

Finally, they believe that their students cannot see any linkage between this course and their major in foreign language learning, thereby lacking incentives in learning this subject. Minh Anh blamed that on the limitations of the course objectives.

From the sharing of Minh An and Minh Anh, the researchers found the following:

Firstly, they were aware of the poor connection between the course Fundamentals to Vietnamese culture and the intercultural competence. In explaining for that poor connection, they blamed the in-class activities, like the presentation, and the course conduct (online learning), but not the materials. They did not recognize the problematicity - the non-dynamic view directing the two books. It is understandable, as the two books have been dominating the academic market since their first publication in mid-1990s. They are so popular that most higher education institutions in Vietnam use the books for their freshmen. When every place of the nation uses the same books, it is hard for one to realize the problematicity.

Secondly, they think that comparing the native culture to foreign cultures is a manifestation of building intercultural competence. According to Baker (2011), a popular misconception of cultural awareness is that it has often been conceived in relation to intercultural communication between defined cultural groupings, typically at the national level. And thus, cultural awareness is often associated with the comparisons between the local culture and the target cultures. However, what meanings could the comparisons bring to the learners? What happens if such comparisons result in the stereotypes and prejudices? Comparison is needed to inform learners upon the cultural diversity, but it is just the first step.

Thirdly, we see the lack of reflectional activities in classroom. Liddicoat (2005) 
states that intercultural competence involves 7 qualities as follows:

- Accepting that one's own and others' behavior is culturally determined.

- Accepting that there is no one right way to do things.

- Valuing one's own culture and other cultures.

- Using language to explore culture.

- Finding personal solutions in intercultural interaction.

- Using L1 culture as a resource to learn about L2 culture.

- Finding an intercultural style and identity

Of the 7 qualities above, qualities 1 and 2 are indeed achievable in classroom of Vietnamese culture. Teachers could guide students with some questions like "How do you feel when your friends/relatives react this way?" or "Is this the only way to respond to a specific situation?", so that students themselves can see their own points of view as well as compare their answers with classmates. This is the time when they realize how their behaviors are pre-determined by cultures and how many diverse ways there are to deal with a problem.

\subsubsection{From students' insights}

Students' insights were taken from a 10-question survey and a follow-up interview which were central on the awareness of students towards culture and their experiences with the course Fundamentals to Vietnamese culture. 263 participants were randomly chosen among second-year students who had just finished the Vietnamese culture course in the previous semester. The two researchers intended to choose second-year students as we wanted to investigate how the course influenced the way learners look at culture. Below are the findings we get from the survey:

In terms of cultural awareness, $77 \%$ participants viewed Vietnamese culture as a fixed set of cultural values, handed down from generation to generation; $17 \%$ participants viewed it as an integration between many different cultures, constantly moving and changing; and merely $6 \%$ thought that there is actually no cultural identity because every cultural practice depends on the network of meanings (i.e. historical context, social context.) that constitute it.

Besides the two main course books, only $13 \%$ of them spent time reading other books of culture. These supplementary books are: Việt Nam Phong tuc - Vietnamese customs (Phan Kế Bính), Thần, người và đất Việt - Gods, people and land of Vietnam (Tạ Chí Đại Trường), Khảo chứng tiền sủ Việt Nam - Researching Proto-Vietnam History (Trương Thái Du), Món ngon Hà Nội-Hanoi delicacies (Vũ Bằng), Hà Nội băm sáu phố phuòng - 36 Streets of Hanoi (Thạch Lam), and some folklores.

About their impressions of the course, nearly $73 \%$ of participants reported that they found it of some help to their second language learning. They wrote that this course would be very useful for those who aimed at being a translator or interpreter. The rest $27 \%$ saw no relationship between the course and their second language learning. A student named Minh Khanh (pseudo-name) said, "Why do we have to study this course? I gained nothing after studying it. It kinda wasted my time."

In regards to classroom activities, the learning procedure is, most of the time, conducted through teachers' lecturing the content of the course books. Students' presentations are occasional, yet the presented knowledge is basically deprived from the legitimate materials without any implications to foreign culture. Self-reflectional cultural activities are totally absent.

From the report of students, we can see the static awareness towards culture and the teacher-centered philosophy of teaching:

The majority of students look at culture as a fixed set of values, which means that culture to them is "virtually synonymous with 
"tradition", or "customary ways of behaving" (Avruch, 1998, p. 16). This perception may not only result from the two books Fundamentals of Vietnamese culture as discussed above, but also from the reference books that students read. Some books such as Viẹt Nam Phong tuc - Vietnamese customs (Phan Kế Bính), Món ngon Hà Nội - Hanoi delicacies (Vũ Bằng), and Hà Nội băm sáu phố phường - 36 Streets of Hanoi (Thạch Lam) are all about "true" customs and traditions of Vietnamese people. The two books Thần, người và đất Việt - Gods, people and land of Vietnam (Tạ Chí Đại Trường) and Khảo chúng tiền sủ Việt Nam - Researching Proto-Vietnam History (Trương Thái Du) somehow delve into the historical cultural Vietnam through the social construction viewpoint; however, the effort to read such books is marginal. The static way of seeing culture implies the conception that there is no sense of struggle, and even when there are struggles, they cannot change or distort any tradition and custom. Culture is, therefore, timeless and has "a changeless quality" (Avruch, 1998, p. 16).

Within teacher-centered philosophy, the report from students seems to match with the teachers'. The design of subject as an online course does not provide the chance for both teachers and learners to discuss back and forth and build up deeper understanding on any subject matter. Besides, students lack motivation in learning this course, more than a quarter of participants saw no support of this subject to their language learning and the rest only find a little usefulness. This should be seriously taken into consideration, as Ford and Roby pointed out, "When a task is not important to a student or it is not an integral element of the student's life, amotivation typically results" (2013, p. 104). "Amotivation results from not valuing an activity (Ryan, 1995), not feeling competent to do it (Bandura, 1986), or not expecting it to yield a desired outcome (Seligman, 1975)." (Ryan \& Deci, 2000). Cultural competence is the core competence in foreign language acquisition, if learners are not aware of its importance, it will be hard for them to become a successful communicator.

\section{Conclusion}

The use of English as the global lingua franca truly highlights the need for an understanding of cultural contexts and a critical mindset to successfully communicate across diverse cultures. If culture continued to be looked at from the culture-ology perspective as fixed sets of values, we are afraid that a culture learner would hold an essentialistic thinking and become vulnerable in a multicultural environment. The two books Fundamentals of Vietnamese Culture were composed in early 1990s, when Vietnam was in Đổi Mới stage- a post-war recovery and toward-modernity stage, and carried the mission of "build an advanced culture imbued with national identity". However, backed up by the arguments in Section 5.1, we believe that the "advanced culture" or the "strong national identity" would impede the learners' integration process, rather than give them the courage to expose to foreign cultures.

In this paper, we suggest two dynamic ways of teaching culture. Firstly, teachers should encourage the use of supplementary materials written by worldwide authors in order to acknowledge students on the theory of multiple truths. Each writer shares their own point of view, thereby adding one more truth to look at an event. Students, instead of presenting what is written in textbooks only, now need to discuss other truths from multiple perspectives. Secondly, teachers and students need to work on some questions like: What historical contexts was a book composed in? For what purposes? What patterns of thoughts that the author stands for? Those questions would provide critical lenses for students and gradually makes them understand that any cultural practices are intermingled in a very complex network of meanings.

Though we do not agree with Cao Xuân Huy (1995) on the comparison of culture 
with water at the illustration, "dẫu có điên đảo ngả nghiêng đến đâu nó vẫn nhanh chóng trở về cái quân thế tuyệt diệu của nó" (No matter how intensely [the water] rolls, [the water] will quickly return to its wonderful stance) (p. 365), we think that water can, to some extent, symbolize the dynamic, non-linear-ness, intertwined-ness of culture, and the constant-changing nature of it. The poem "New Age" of Bertolt Brencht says it all:

"A new age does not begin all of a sudden. My grandfather was already living in the new age

My grandson will probably still be living in the old one.

The new meat is eaten with the old forks.

It was not the first cars

Nor the tanks

It was not the airplanes over the roofs

Nor the bombers.

From the new transmitters came the old stupidities.

Wisdom was passed on from mouth to mouth."

In this era of globalization, culture is best thought of not as a bounded unit but as a set of overlapping performative language games that flow with no clear limits or determinations within the global whole of human life (Baker, 2004 , p. 45). The critical cultural awareness thereby serves to mitigate the inferiority complex among learners, help them avoid being influenced by the daily media praises of a dream European-American culture; and most importantly, pass judgements in order to become a global citizen.

\section{References}

\section{Vietnamese}

Cao Xuân Huy (1995). Tu tương phương Đông gơi nhũng điểm hình tham chiếu. Hà Nội: NXB Văn học

Phan Ngọc (1996). Văn hoá Việt Nam và cách tiếp cận móit. Hà Nội: NXB Văn hoá thông tin.
Trần Ngọc Thêm (1996). Tìm về bản sắc văn hoá Việt Nam. TPHCM: NXBTP Hồ Chí Minh.

Trần Ngọc Thêm (1997, tái bản lần 2). Co sở văn hoá Việt Nam. Hà Nội: NXB Giáo dục.

Trần Quốc Vượng (1998). Co sở văn hoá Việt Nam. Hà Nội: NXB Giáo dục.

\section{English}

Al-Marky, N. (1979). Reviewing the book 'Orientalism' by Said Edward (1978). USA: Vintage Books.

Alptekin, C. (2002). Towards intercultural communicative competence in ELT. ELT Journal, 56(1), pp.57-64.

Avruch, K. (1998). Culture and conflict resolution. Washington DC: United States Institute of Peace Press.

Baker, C. (2004). The SAGE dictionary of cultural studies. CA: SAGE Publications.

Baker, W. (2011). From cultural awareness to intercultural awareness: Culture in ELT. ELT Journal, 66(1), pp.62-70.

Byram, M. (1997). Teaching and assessing intercultural communicative competence. Clevedon, UK: Multilingual Matters.

Byram, M. (2008). From foreign language education to education for intercultural citizenship: Essays and Refections. Clevedon: Multilingual Matters.

Cheboksarov, N. N. \& Cheboksarova, I. A. (1971). Peoples, Races, and Cultures. Moscow, Russia: Science.

Crozet, C. (1996). Teaching verbal interaction and culture in the language classroom. Australian Review of Applied Linguistics, 19(2), pp.37-58.

Ford, V. B. \& Roby, D. E. (2013). Why do high school students lack motivation in the classroom?. Global Education Journal, 2013(2).

Houghton, S. A., Furumura, Y., \& Lebedko, M. (Eds.). (2014). Critical cultural awareness: Managing stereotypes through intercultural (language) education (pp. 204-220). Newcastle upon Tyne, U.K.: Cambridge Scholars Publishing.

Goscha, C. (2016). Vietnam: A new history. New York: Basic Books.

Harari, Y. N. (2014). Sapiens: A brief history of humankind. Canada: McClelland \& Stewart.

Le, M. K.(2016). Racism in Vietnamese Scholarship (Part 1). Retrieved August 30th, 2019 from https:// leminhkhai.wordpress.com/2016/03/02/racism-invietnamese-scholarship-part-1/

Liddicoat, A. J. (2005). Teaching languages for intercultural communication. Doctoral dissertation. Australia: Griffith University, School of Languages and Linguistics. 
Newton, J. (2016). Cultivating intercultural competence in tertiary EFL programs. Crossing Borders in Language Teaching and Business Communication: Proceedings of the 11th ELT conference at AE CYUT. (pp. 1-22). Chaoyang University of Technology, Chaoyang, Taiwan, 27 May 2016.

Nugent, K., \& Catalano, T. (2015). Critical cultural awareness in the foreign language classroom. Faculty Publications: Department of Teaching, Learning and Teacher Education, 194.

Ryan, R. M. \& Deci, E. L. (2000). Self-determination theory and the facilitation of intrinsic motivation, social development, and well-being. American Psychologist, 55, pp.68-78.

Said, E. W. (1978). Orientalism. New York: Pantheon.

Sercu, L. (2004). Assessing intercultural competence: A framework for systematic test development in foreign language education and beyond. Intercultural Education, 15(1), pp.73-89.

Spencer-Oatey, H. (2012). What is culture? Acompilation of quotations. GlobalPAD Core Concepts. Available at GlobalPAD Open House http://go.warwick.ac.ul/ globalpadintercultural

Truong. M.H. \& Phung. H. T. (2018). 'Fresh off the boat' and the model minority stereotype: A Foucauldian discourse analysis. VNU Journal of Foreign Studies, 34(5), pp.85-102.

Wittgenstein, L., 2001. Philosophical investigations. London: Blackwell.

Yulita, L. (2013). Critical pedagogy: Stereotyping as oppression. In: Critical Cultural Awareness. Cambridge Scholars Publishing, Newcastle upon Tyne, pp.204-220.

\title{
NHẬn THỨC VĂN HOÁ CÓ PHÊ PHÁN: VĂN HOÁ VIIẸT NAM CÓ NÊN ĐƯợC TIẾP CậN THEO MộT HƯớNG KHÁC?
}

\author{
Đỗ Như Quỳnh, Đào Thị Diệu Linh \\ Truờng Đại học Ngoại ngũu, Đại học Quốc gia Hà Nội \\ Phạm Văn Đồng, Cầu Giấy, Hà Nội, Việt Nam
}

Tóm tắt: Nhận thức văn hoá có phê phán- một thành tố chủ chốt trong khung năng lực giao tiếp liên văn hóa của Byram (1997) - đã nhấn mạnh tầm quan trọng của việc đào tạo kỹ năng tư duy phê phán cho người học ngoại ngữ. Nhiều nghiên cứu về cách phát triển nhận thức văn hóa có phê phán đã được thực hiện trong các lớp học ngôn ngữ; tuy nhiên, chưa có nghiên cứu nào mà chúng tôi tìm được lấy lớp học văn hóa bản địa là bối cảnh để nâng cao nhận thức này. Trong bài viết này, nhóm tác giả muốn nhấn mạnh tính cần thiết của việc thúc đẩy nhận thức văn hoá có phê phán trong lớp học văn hóa bản địa. Chúng tôi nhận ra một số rào cản khiến việc giảng dạy văn hóa Việt Nam tại trường đại học (trong giới hạn một ví dụ tại trường ĐH Ngoại ngữ - ĐHQGHN) hiện nay chưa thể giúp nhận thức văn hoá có phê phán cho người học. Những rào cản nói trên nằm ở tài liệu học tập, cụ thể là hai cuốn giáo trình về văn hóa Việt Nam và các hoạt động học tập trên lớp. Cuối cùng, chúng tôi đề xuất một số ý tưởng để làm cho việc dạy và học có tính phê phán hơn.

Từ khoá: nhận thức văn hoá có phê phán, văn hoá Việt Nam, thuyết bản chất luận, tính động 